\begin{tabular}{|l|l|l|}
\hline \multicolumn{2}{|c|}{ PublisherInfo } \\
\hline \hline PublisherName & $:$ & BioMed Central \\
\hline \hline PublisherLocation & $:$ & London \\
\hline \hline PublisherImprintName & $:$ & BioMed Central \\
\hline \hline
\end{tabular}

\title{
MT1-MMP-deficient mice develop connective tissue abnormalities
}

\begin{tabular}{||l|l|l||}
\hline \multicolumn{2}{|c||}{ ArticleInfo } \\
\hline \hline ArticleID & $:$ & 229 \\
\hline \hline ArticleDOI & $:$ & $10.1186 /$ ar-1999-66749 \\
\hline \hline ArticleCitationID & $:$ & 66749 \\
\hline \hline ArticleSequenceNumber & $:$ & 186 \\
\hline \hline ArticleCategory & $:$ & Paper Report \\
\hline ArticleFirstPage & $:$ & 1 \\
\hline \hline ArticleLastPage & $:$ & 3 \\
\hline \hline & $:$ & RegistrationDate : 1999-11-11 \\
ArticleHistory & $:$ & OnlineDate $:$ 1999-11-11 \\
\hline \hline ArticleCopyright & $:$ & Current Science Ltd1999 \\
\hline \hline ArticleGrants & $:$ & \\
\hline \hline ArticleContext & $:$ & 130753311 \\
\hline \hline
\end{tabular}


Aff1 Imperial College School of Medicine, London, UK

\section{Keywords}

Arthritis, bone metabolism, gene-targeting, matrix metalloproteinases, mice

\section{Context}

MT1-MMP is a membrane-bound matrix metalloproteinase (MT-MMP) that can mediate pericellular proteolysis of extracellular matrix components. Matrix metalloproteinases (MMPs) form a family of zinc endopeptidases that play an important role in mediating stromal remodelling such as occurs during cell migration, angiogenesis and wound healing. While most MMPs are secreted, MT-MMPs are type I membrane proteins with a single transmembrane domain and an extracellular catalytic domain. Their membrane location suggests that they may mediate pericellular proteolysis. Mouse strains deficient in several individual MMPs have been previously developed and they showed little or no defect in their development. To establish the biological role of MT1-MMP in modelling of skeletal and extraskeletal connective tissues during development.

\section{Significant findings}

MT1-MMP-deficient mice displayed severe growth impairment that became evident as early as 5 days. Approximately $30 \%$ of the mutant mice died from wasting before weaning age. The gene-targeted mice gradually showed a severe skeletal phenotype with craniofacial dysmorphisms, osteopenia, dwarfism and fibrosis of soft tissues. They also developed severe generalised arthritis, characterised by a hypercellular and vascularised synovial tissue and destruction of articular cartilage. Ankylosis and progressive fibrosis of the dermis was observed in older animals. The cranial abnormalities were caused by an impaired removal of the calvarial cartilage primordia that was gradually transformed into a fibrotic vestige. The postnatal development of the epiphyseal (secondary) ossification centres was markedly delayed due to a general defect in the vascularisation of hyaline cartilage. BrdU labelling revealed that the chondrocyte proliferation was significantly reduced in growth plates in adult mutant mice. The progressive osteopenia observed in the adult gene-targeted animals was a result of increased bone resorption, as well as diminished bone formation. Osteoprogenitors cells from the bone marrow of mutant mice showed impairment of osteogenic capacity and of collagenolytic activity. In addition MT1-MMP deficient skin fibroblasts were incapable of degrading type I collagen matrix. 


\section{Comments}

This paper elegantly demonstrates the central role of MT1-MMP in connective tissue metabolism and illustrates nicely the importance of stromal collagenous remodelling for development and growth . Notably, the deficiency of MT1-MMP causes the development of severe arthritis. This finding is particularly interesting in view of the many reports in the literature showing overexpression of individual MMPs in human arthritis. This paper also raises some concern on the use of MMP inhibitors in arthritis therapy. The authors have not yet addressed the pathogenesis of arthritis in the MT1-MMPdeficient mice, but their data would suggest that the arthritic changes develop as a result of inappropriate cartilage remodelling during growth.

\section{Methods}

MT1-MMP-deficient mice were generated using a conventional replacement type targeting vector. The absence of MT1-MMP was confirmed by northern blot analysis. The skeletal development was monitored by X-ray images and by histological sections. Bone formation was studied by in vivo labelling techniques using calcein. Osteogenic capacity of bone marrow derived stromal cells was tested by isolating clonogenic osteoprogenitor cells from mutant mice and normal littermates and by probing their ability to form bone in a transplantation assay. The capacity of MT1-MMP-deficient fibroblasts to degrade type I collagen fibrils was assessed by plating the cells on a 24-well plates coated with a type I collagen fibril film with or without the addition of TNFa/IL-1?. The amount of collagen degraded by the cells derived from the wild-type and the MMP-deficient mice was compared by staining the residual collagen fibrin film with Coomassie blue.

\section{Additional information}

For the cartilage biologists' perspective, see related report

\section{References}

1. Holmbeck K, Bianco P, Caterina J, Yamada S, Kromer M, Kuznetsov SA, Mankani M, Robey PG, Poole AR, Pidoux I, Ward JM, Birkedal-Hansen H: MT1-MMP-deficient mice develop dwarfism, osteopenia, arthritis, and connective tissue disease due to inadequate collagen turnover. Cell . 1999, 99: $81-92$.

This PDF file was created after publication. 